\title{
Knowledge for the West, Production for the Rest?
}

\section{Bregje van Eekelen}

To cite this article: Bregje van Eekelen (2015) Knowledge for the West, Production for the Rest?, Journal of Cultural Economy, 8:4, 479-500, DOI: 10.1080/17530350.2014.909367

To link to this article: http://dx.doi.org/10.1080/17530350.2014.909367

\section{曲 Published online: 28 May 2014.}

Submit your article to this journal

\section{Џll Article views: 82}

Q View related articles $₫$

\section{View Crossmark data $₫$}




\section{KNOWLEDGE FOR THE WEST, PRODUCTION FOR THE REST? \\ Narratives of progress and decline in knowledge economies}

\section{Bregje van Eekelen}

Received 27 Jun 2013; Accepted 24 Mar 2014

This article develops the argument that a 'knowledge economy,' despite its cheerful optimism, is also an elegant incarnation of the demise of Western economies. An analysis of policy documents, research statements, and national accounts reveals this paradoxical coexistence of anxiety and progress in the discourse on knowledge economies. While the concept is often hailed as a temporal concept (superseding other forms of economic production), this article argues that a knowledge economy is best understood as a spatial concept - it is a way of contending with global reorganizations of production. This spatial approach is elaborated to tackle three paradoxes. (1) A knowledge economy enfolds defeat with progress. (2) A knowledge economy downplays the importance of industrial labor and simultaneously depends on it to materialize its ideas. (3) While seemingly intangible and ephemeral, a knowledge economy is fixed in place in national economies through government and corporate policy (including through the emergent phenomenon of 'knowledge-adjusted gross domestic products'). A spatial approach provides a view of the tenuous global interconnections and specific conditions that prop up a knowledge economy, and shows how the concept is mobilized to redraw the map so that endangered economies can regain their challenged sense of centrality in a world economy.

KEYWORDS: knowledge economy; creativity; national accounts; geography of value; global capitalism

A 'knowledge economy' is often presumed to mark a new stage in economic production. This temporal narrative suggests a natural development from an industrial economy to a service economy, followed by a knowledge economy. A narrative of stages allows for a cheery sense of progress: knowledge economies equal the avant-garde of late capitalism. Upon closer look, a knowledge economy turns out to be more ambivalent. I argue in this article that a knowledge economy is better understood as a spatial concept it is a way of grappling with the global reorganization of production. Whereas the temporal view pits a knowledge economy at the pinnacle of economic development, a spatial approach provides a view of the global interconnections and specific conditions that are necessary to keep a knowledge economy afloat. This article tackles three paradoxes. (1) A knowledge economy enfolds defeat with progress. (2) A knowledge economy downplays the importance of industrial labor and simultaneously depends on it to materialize its ideas. (3) While the emphasis on intangible material presents a 
knowledge economy as peripatetic, it is a matter of government and corporate policy to ensure a knowledge economy is firmly anchored in (Western) national economies. Taken as a spatial concept, the tenuous contingencies that a knowledge economy banks on e.g. access to low-waged industrial labor, the repatriation of profits through intellectual property (IP) protection - come in full view. Rather than a critique or a celebration of the concept, this alternative approach redirects the discussion toward an assessment of current and future production arrangements.

\section{Paradox I: Progress and Decline}

At the beginning of the 21st century, America stands at the dawn of a conceptual economy in which insight, imagination and ingenuity determine competitive advantage and value creation. To succeed in this hyper-competitive, fast-paced global economy, we cannot, nor should we want to, compete on low wages, commodity products, standard services, and routine science and technology development. (Council on Competitiveness 2006, p. 6) ${ }^{1}$

How are we to understand the conundrum that that which has for the past 20 years been - often triumphantly - heralded as the next stage in capitalism, as the future of Western economies, as a pinnacle of progress - a 'knowledge economy' - usually pops up in a context of abandoned factories, derelict office buildings, and other traces of corporate wastelands, amidst material reminders of other economies that once offered hope, work, and visions of an industrious future $?^{2}$ A knowledge economy, or creative society, is a paradoxical concept. It is cast as a narrative of progress and, often simultaneously, as a narrative of anxiety about economic decline.

A knowledge economy is on the one hand a compelling concept. It speaks to a discourse of civilization: what higher energy than 'brainpower'? The traffic in knowledge and in ideas appeals to a sense of being part of an 'advanced' and advancing society. What could be more advanced than using the clean energy of 'insight, imagination and ingenuity' to fuel an economy? (Council on Competitiveness 2006, p. 6). Its resonances with a civilizational discourse make it more than simply another means to accrue capital: the concept offers a sense of progress, not least because it intimates that the mind is the vital tool, a quite literal allusion to the power of thought.

A knowledge economy is on the other hand, and simultaneously, a victorious recoding of economic demise. It has been invoked to resuscitate the depressed economy of North Carolina, to provide an alternative industry to the abandoned shipyards of Britain, or to revivify the derelict factory buildings around Amsterdam that once teemed with industrial activity. ${ }^{3}$ Working with the mind offers not only a path toward a civilizational pinnacle but also a last resort. The USA and Europe, long before the financial meltdown, were facing a crisis in economic production. As the epitaph suggests, they could not compete on most fronts, be they manufacturing, standard services, or routinized technological areas. Faced with growing economic competition currently epitomized by the industrious low-wage activities in China and India, competition based on manufacturing efficiency was considered a lost cause. Even the production of standardized services no longer promised a steady future. ${ }^{4}$ Instead, the narrative of a knowledge economy imparted that the future of these sites was conceptual. Hence, since the 1990s, the elusive 
concepts of 'creativity' and 'knowledge' became the answer to deindustrialization in Western Europe and the USA, and the concomitant emergence of - and access to - lowwage industrial labor elsewhere, in maquiladoras, transnational trading zones, and subcontracted supply chains. ${ }^{5}$ For all its cheerful optimism, a knowledge economy is therefore also an elegant incarnation of the demise of industrial economies. Hence, the narrative of ideas and ideational work - banking on innovation and creativity - functions both as a celebration of the latest stage in capitalism and as a distressing symbol of the last resort of post-industrial economies.

The paradoxical coexistence of optimism and pessimism is not my invention. It is based on an analysis of policy documents, research statements, and newspaper articles. These texts have a knowledge economy as their object, and the coexistence of anxiety and progress is, upon closer look, at the heart of their articulations. Nothing I say here is not already present in these texts, but somehow the concept of a knowledge economy can absorb its own negativity, its warnings, its anxious mulling for ways to curb economic production from flowing every which way. That is, it does and does not represent its own split personality. A knowledge economy does in the sense that it often offers the reader the ruinous terms of its making in popular descriptions such as 'Globalization, outsourcing, and the emphasis on innovation and creativity are forcing businesses to shift at a dramatic rate from tangible to intangible investments' (Mandel et al. 2006, n.p., emphasis mine). But it does not represent its anxious conditions of existence in another way. Somehow, the emphasis on the 'growing value of innovation, services and intangibles' makes it palatable that a knowledge economy connotes an inability to compete in manufacturing as well as 'areas that were once the exclusive domain of developed communities,' such as software, accounting, and the production of high technology goods (Council on Competitiveness 2006, p. 7). The promise of potential growth helps digest the ruination it seeks to redress. ${ }^{6}$ What the texts have in common is that they translate and fold a crisis in economic production into a new conceptual stage, a stage that sounds promising and civilizational: we are moving forward into a conceptual economy. ${ }^{7}$ This forward motion through a 'natural history' of a set of successive stages partakes in the making and temporary anchoring of the concept of a knowledge economy. ${ }^{8}$ The story of different economies superseding each other produces unity in the present and offers a narrative of progress for the foreseeable future (Gibson-Graham 1996; Ferguson 1999). The unity that is offered is analogical: labor, natural resources, and physical inputs in industrial economies are replaced by creativity, intellectual resources, and intangible inputs in knowledge economies. This analogy is suggestive but also warrants pause. For what could it mean that labor is somehow displaced by ideas as the center of economic production?

This analysis concentrates on policy documents, research statements, and newspaper articles that focus on the USA and Europe, arguably the first sites where the concept of a knowledge economy was mobilized. ${ }^{9}$ Doing so allows me to investigate the nexus in which this economic reordering first emerged. The following passage on Europe's economy is for instance eerily similar to the one I quoted in the epitaph on the USA:

Europe's knowledge economy is central to its future economic competitiveness. In a world characterized by strong competition, economic interdependence and low wages in emerging economies, Europe cannot rely on low wage, low value-added production in order to generate economic growth and create new jobs. Instead, Europe must focus its efforts on areas where it has a potential competitive advantage: the production of high value- 
added goods and services, embodying a high level of physical and human capital and knowledge. (European Policy Centre 2009, n.p., emphasis mine) ${ }^{10}$

Again, a rather devastating picture is reframed as a bright future, characterized by an orientation toward knowledge production and other activities that could wield high profits. After its emergence in the 1990s, the concept of a knowledge economy has become modular. ${ }^{11}$ The ambivalent discourse has been mobilized in a variety of contexts that - I suspect - are best characterized as suffering from a prolonged crisis in economic production, the USA and European states among them. What I mean by crisis is exactly the picture painted (and obfuscated) by the policy briefs: an inability to compete in manufacturing and standardized services, an evacuation of industrial and service production to low-wage sites, a quandary of what competitive export products could offset the rise in imports of consumer goods, and a concern about what jobs might be taken up in post-industrial sites. Moreover, and I will return to this point in the second half of this article, a knowledge economy is not just 'located' in some of these sites, but the discourse actively seeks to recreate geographies of value for these sites. In that sense, I take the concept of a knowledge economy to be a mapping device.

\section{The Present Nexus}

China has established itself as the heart of the world economy, but it is not the brains. (BBC News, August 10, 2007)

The key to productivity was knowledge, not sweat. (Drucker 1968, p. 271)

How has the valorization of intangibles in the regime of an economy - and the embrace of ideas as a source of potential profits - come to be related to a narrative of growing competition and anxieties about 'falling behind'? The short answer: it was through growing competition in the realm of industrial labor that 'ideas' (not labor!) have come to be seen as productive of profits.

An example from the recent present exemplifies this shift. It starts with a voice-over declaring that 'The 20th century was the age of property, that is, land. The 21 st century is the age of intellectual property, of ideas.' This periodization, presented in a documentary on creative commons titled RIP: A Remix Manifesto, could be read in two ways: as a statement about continuity or as a statement about change. In terms of continuity, it states: that which connects both the past and the present century is a fixation on property. The periodization is often read, however, in another way, as a statement about a particular transformation from industrial production to knowledge production, exemplified in the claim that in this new century 'wealth resides in the products of the mind, in intellectual creations. ${ }^{12}$ This claim was made by Bruce Lehman, the former undersecretary of IP in the Clinton Administration, in the same ReMix documentary. In this second interpretation, the adjective 'intellectual' is what seems distinct both for the new century and for the concept of $\mathrm{IP}$, rather than property proper. $^{13}$

Lehman continued his narrative of how wealth had come to reside in the mind with a reflection on the spatial organization of economic production. All the tangible products bought in the USA were made in China, he explained, 'you [could] hardly buy something that [was] made in the USA.' Lehman saw this situation as a product of his administration's policies. 'We opened up our markets, with the idea that we would abandon low wage manufacturing jobs and compensate for the loss with higher wage high-tech information - 
more intangible-based jobs. ${ }^{14}$ It seems quite an audacious and consequential step to make it a matter of policy to 'abandon low wage manufacturing jobs,' those very jobs that had until recently provided millions with relative and partially unionized security. (These jobs, indeed, are often coded as fruitless in the context of a knowledge economy.) Stronger yet, how could the step to dismantle manufacturing be so easily recoded as a step forward?

One process that contributed powerfully to the valorization of ideas - and the concomitant devaluation of manufacturing labor - took place in 1995, during Lehman's tenure as undersecretary of IP. It has rarely been mentioned in relation to a knowledge economy - let alone in the context of creativity, ingenuity, and ideas - but in 1995, the value of the dollar rose rapidly. This was an effect of what has been called the 'reverse' Plaza Agreement. Ten years earlier, in 1985, following the Plaza Accord, the value of the dollar had been lowered deliberately, mostly at the expense of Japanese and German industries (Matsuura et al. 2003, p. 1001). The resulting depreciation of US export prices and the rise of US import prices had allowed for some recovery and growth in US manufacturing in the ensuing decade. In the early Clinton years, consequently, manufacturing was doing better, and seemed to be of central importance to the health of the US economy. But in 1995, this policy was quite abruptly shelved and reversed. Brenner has described the reverse Plaza Agreement as nothing less than a break in the organization of the US economy (2009). With US export prices soaring and US import prices plummeting, US-based manufacturing was as good as given up - a claim echoed by Lehman above. ${ }^{15}$ In its stead, the internal US economy would revolve around '[c]onstruction, retail trade, and the non-traded goods sector' (Brenner 2009, p. 14). Moreover, consumption would replace investment, and imports would take center stage 'at the expense of exports' (Brenner 2009 , p. 14). But perhaps most importantly, the agreement amounted to an 'all out embrace' of a reorganization of production 'by way of supply chains, foreign direct investment and the relocation of industry to lower wage venues, not least China' (Brenner 2009, p. 14). ${ }^{16}$

In what follows I argue that this reorganization of the production line undergirds the interest in - and organization of - intangibles. That is, assertions such as Lehman's claim that 'wealth resides in the products of the mind, in intellectual creations' need to be situated in these specific socioeconomic contexts - they are, to a considerable degree, dependent on them. Wealth resides in the mind, for example, if the value of a currency is high enough to warrant the evacuation of industrial production. Without a strong currency, the valorization of knowledge, creativity, and ideas would need to be reconsidered, as there would be no low-cost industrial labor elsewhere to materialize it.

\section{The Category of Intellectual Labor - A Prehistory}

Whereas I claim above that the idea that wealth resides in the mind - and that ideas are valuable - is contingent on a set of very particular socioeconomic conditions, there is also another, more historical condition of existence that underpins the very differentiation of wealth in the mind and manual work. A knowledge economy, presumably, is an economy in which manual labor - the execution of industrial tasks - is no longer present and necessary, and instead, many workers are eking out a living using their disembodied minds. ${ }^{17}$ A foundational aspect that animates the concept of a knowledge economy is the split between manual and intellectual labor. One of the historical processes in which knowledge, or 'skills,' was deliberately and systematically separated from manual labor was 
Frederick Taylor's study of work labeled scientific management, developed at the turn of the previous century. In order to understand the present crisis in economic production, then, let us briefly turn to another moment of crisis in US productivity, in 1911.

'We can see our forests vanishing,' Taylor wrote, 'our water-powers going to waste, our soil being carried by floods into the sea; and the end of our coal and our iron is in sight' (1911 [1998], p. iii). According to Taylor, this alarming wastefulness was small potatoes compared to the squandering of what President Theodore Roosevelt had called the 'national efficiency' - the waste of human labor. The suggestive analogy between the exigencies of vanishing natural resources and the 'less visible, less tangible' waste of human labor configures the overture to Taylor's The Principles of Scientific Management (1911 [1998]). By framing the problem in terms of a crisis in labor efficiency comparable to - or even eclipsing - the squandering of natural resources, shifts in the organization of the economy and the conceptualization of production seemed reasonable.

Taylor himself had run into the conundrum of labor efficiency as a foreman in Midvale Steel Company in Philadelphia. Realizing that the work of steelmaking could be accomplished faster, he described his conundrum in terms of an antagonism between capital and labor:

He [Taylor] found ... that his efforts to get the men to increase their output were blocked by the fact that his knowledge of just what combination of depth of cut, feed, and cutting speed would in each case do the work in the shortest time, was much less accurate than that of the machinists who were combined against him. (Taylor 1907, p. 5, paragraph 17$)^{18}$

In other words, as a foreman he had precious little knowledge of the refracted know-how that was embedded in the process that he was to supervise. Taylor detailed the time-andmotion study of steelworkers' operations whereby knowledge was actively codified and transferred to management in On the Art of Cutting Metals (1907). ${ }^{19}$ Through a study of decomposed units of labor, he sought 'to investigate the laws of cutting metals with a view of obtaining a knowledge at least equal to that of the combined machinists who were under him' (Taylor 1907, p. 5, paragraph 17). ${ }^{20}$ Initially, Taylor estimated that this investigation would take six months. Instead, it took him 26 years (Taylor 1907, p. 5, paragraph 18). ${ }^{21}$

His studies and the transformations they set in motion indexed a historical shift in the organization of production. In the midst of this reorganization, workers were quite deliberately alienated from the intellectual features of their labor. Others would think for them. Taylor's project was an explicit attempt to solidify the position of 'management' by taking control over and centralizing the refracted knowledge of workers and their foremen. In his words, it was 'aimed at establishing a clear-cut and novel division of mental and manual labor throughout the workshops,' and it 'relegate[d] the entire mental parts of the tasks in hand to the managerial staff' (1998 [1911]). The new regime of management was tasked to oversee the workers and to design the labor process. Managers were not so much the possessors but the processors of knowledge:

we propose to take all the important decisions and planning which vitally affect the output of the shop out of the hands of the workmen, and centralize them in a few men, each of whom is especially trained in the art of making those decisions and in seeing that they are carried out. (Taylor 1907, p. 28, paragraph 124) ${ }^{22}$ 
This transfer of knowledge enabled a conceptual shift that has been a foundational condition for the current reordering of the economy. Alienated knowledge became a thing in itself. Alfred Sohn-Rethel described the sea change that ensued in the Taylorist schemes in terms of a fetishism of knowledge: 'The intellectual tasks vested in this management were not seen as representing the workers' minds but as deriving directly or indirectly from science and scientific technology' (1978, p. 158). Decomposing the manual work into 'unit times,' Taylorized labor amounted, at least on paper, to 'human labour [sic] made into a technological entity, homogeneous with the machinery, directly adaptable.' It was labor that could 'be inserted or transformed into [a technological entity] without any difficulty of conversion' (Sohn-Rethel 1978, p. 155).

It is important to note that intellectual labor, under Taylor's watch, became separated from manual labor in the name of standardization, rationalization, and efficiency (see also Braverman 1974, p. 63). Paradoxically, as I have shown elsewhere, the systematicity of 'science,' as well as the management that arose from scientific management, became the embodiment of that which had to be 'overcome' and spurned in order to produce knowledge and to work 'creatively' in later articulations of knowledge economies (Van Eekelen 2010). However, whereas knowledge work is nowadays often associated with a freedom, intuition, and creativity that is deemed incompatible with managed labor, it was exactly in the standardization of labor - broken down in time-units - that the very separation of manual and intellectual labor, and the subsequent interest in - and commodification of - the latter, came about. Similarly, efficiency, a word that is eschewed in contemporary celebrations of intellectual labor, underpinned the critical transfer of knowledge about the labor process from the workers to the managers (deskilling the former, see Braverman 1974). This transfer forms, I argue, one of the mainstays of a knowledge economy.

\section{Paradox II: Shifting Economic Production}

In the previous sections, I have addressed two foundational aspects that animate the concept of a knowledge economy. I discussed the historical specificity of conceptualizing manual and intellectual labor as separable entities. This separation implied a number of notable shifts in the production process: first, workers were no longer cast as embodied thinkers; and second, a regime of management emerged to control the production process, and consequently, knowledge came to be seen as something alienated from the laboring body/mind. Standardization of the labor process lay at the heart of these Taylorist reorganizations of production. I also drew attention to the necessity of access to low-wage industrial labor to materialize the value of knowledge, creativity, and ideas, access that was dependent on a global reordering of production. Importantly, this standardized, low-wage human labor is the backbone of a knowledge economy. Despite its glow of being 'beyond' industrial economies - and a departure from purportedly mind-numbing notions like efficiency, standardization, and productivity - a knowledge economy, rooted in this gash between mental and material labor, is also a sign of the continued or even soaring importance of industrial labor. One of the paradoxical effects in a knowledge economy may indeed be that it banks on more and more (rather than less) Taylorized industrial labor - the very labor eschewed in the term knowledge economy - albeit carried out elsewhere, in maquiladoras, transnational trading zones, and subcontracted supply chains. $^{23}$ 
Increasing efficiency and geographical plasticity of standardized labor contributed, in a sense, to the recent crisis in economic production. As discussed in the first section, competition based on manufacturing efficiency was, in the discourse of a knowledge economy, framed as a lost cause. The Council on Competitiveness described the field of disappearing industrial production and service work as follows:

Generally, if a problem can be solved by a rule or a straightforward process, a computer (or someone using a computer in a developing economy) will be able to do it. Call center work, for example, is heavily scripted, and jobs in this area are being lost not only to facilities in India and elsewhere, but also to speech recognition software. (Council on Competitiveness 2006, p. 90)

Anything that can be standardized, in other words, could be done by either a computer or a low-wage worker. ${ }^{24}$

A common thread that has been running through the emergence of creativity, ingenuity, and ideation as profitable practices is that it offered a sanctuary from all this work that was guzzled up by low-wage workers and by machines - the labor that was standardized. How though can knowledge form a sanctuary from the material reminders of the impossibility of competing on the level of production? Creativity and knowledge were, first of all, allegedly the only things that resist standardization. ${ }^{25}$ And second, they were presumed to be geographically sticky (see below). Invocations of a knowledge economy suggest indeed that new bearings could be found in ideas:

The United States must focus on its strengths - on what it means to be American. We must innovate and embrace the opportunities of the rapidly emerging, high-value conceptual economy. It is increasingly clear that the most important competition is being fought in the arena of ideas, learning and delivering new kinds of value to the marketplace. (Council on Competitiveness 2006, p. 6)

Rewriting history, the Council on Competitiveness situated the import of ideas not just in the present and future, but in the past as well:

Looking back at the tremendous growth of America's gross domestic product over the past half century, information and ideas have been equally, if not more, important than materials and manpower to sustaining America's economy. (Council on Competitiveness 2006)

Note that 'what it means to be American' was recoded here as being flexible and innovative, whereas being 'efficient' or 'hardworking' may have connoted being American not too long ago. At the very moment, however, that manufacturing labor may actually be rising in importance, there is a rather startling conceptual shift away from people and laboring bodies as sources of economic production toward nearly disembodied ideas as generators of profits (and of what it means to be American). ${ }^{26}$ Hence, one of the paradoxical characteristics of a knowledge economy is that it connotes both a decrease and an increase in the importance of manufacturing labor. Its significance decreases with a disappearing memory of embodied labor, and a rally to see ideas as prime sources of profit. And at the same time, the importance of manufacturing increases because a knowledge economy is critically dependent on ready access to manufacturing labor elsewhere. 


\section{Paradox III: Geographies of Value}

The 1995 reverse Plaza Accord posed, in the words of Brenner, 'an immediate and quite fundamental question. What would henceforth sustain the U.S. economy's forward motion, and that of a world economy that so depended upon it?' (2009, p. 15). I speculate that a knowledge economy has crystallized as a partial answer. Ideas became valuable precisely because the materialization of these ideas took place elsewhere, and a profitable knowledge society was in that sense premised on that which it was supposedly beyond: industrial production. ${ }^{27}$ With its embrace of this spatial reorganization of production, a knowledge economy became a way to 'produce' and retain profits in the West. ${ }^{28}$

Whereas the current availability of low-waged labor and the concurrent evacuation of industrial production is the anxious order that makes a knowledge economy possible, it also underpins the renewed interest in the severance of tangible and intangible things. The last two decades have witnessed a growing emphasis on intangibles as separable from the tangibles in which they are embodied, and an emerging regime that codifies this split. This regime, which materializes in IP laws, in accounting rules, and in economic models, seeks to map, measure, and manage knowledge. ${ }^{29}$ The valorization of ideas is backed by an organization and determination of value that marks knowledge economies as competitive and 'high-value' economies. ${ }^{30}$ High value is attributed to innovation, and low value to manufacturing, whereas it could be argued that the actual production of profits took place in a reverse order - profits were realized through manufacturing, despite of, or rather thanks to, low wages. The legal framework of IP and the attribution of value have thus been organized in such a way that design, ideas, and knowledge could be recognized as the origins and motors of profits (even when, again, the material production is taking place elsewhere). ${ }^{31}$

In this spatial organization of production, knowledge - despite its evanescent qualities - is actively made to be geographically sticky. It is not meant to move:

Corporate $R \& D$ remains the least internationalized activity of multinationals; production, IT, finance and back office operations are significantly more globalized. Research intensive activities often represent the core value generators of a firm, and companies are reluctant to move them far afield (particularly to countries where protections for intellectual property may be weak). (Council on Competitiveness 2006, p. 69, emphasis mine)

Here I return to an earlier point: what matters in IP is not the 'intellectual' part - even though that quality is often stressed as being special and charismatic - but the property part. It is exactly not the intellectual part that matters as property, but the fact that the ownership of IP connotes control of the chain of (material!) production. It ensures the repatriation of profits made overseas. ${ }^{32}$

Let me provide one example of this geography of value. The back of an iPod says 'Designed by Apple in California. Assembled in China.' Businessweek has argued that '[w] here the gizmo is made is immaterial to its popularity,' that is, the assemblage in China is a random, inconsequential detail. My point is twofold. First, Businessweek did not say 'where the gizmo is designed is immaterial.' And second, it glossed over the point that if there were no factories that would produce iPods at low costs, the whole concept of iPods (or Apple) might not exist. Instead, the magazine stressed the immaterial aspects: 'It is great design, technical innovation, and savvy marketing that have helped Apple Computer sell more than 40 million iPods.' It is precisely with these kinds of fetishistic celebrations of the 
power of thought that proponents of knowledge and conceptual economies have come to claim that most profits are realized in the traffic of ideas. ${ }^{33}$ The Council on Competitiveness argued exactly that: in the face of the disintegrated production chains (popularized after the reverse Plaza Agreement) 'innovation is increasingly the source of value and competitive advantage.' It continued:

Manufacturing still drives global trade, but value increasingly comes from the 'service wrap' and the ideas bound up in products. Critical investments are not only those made into new fixed assets, like machinery and real estate, but increasingly those in knowledge, branding and other intangible assets. (Council on Competitiveness 2006, p. 13)

According to this passage, manufacturing is still at the center of trade, but profits are realized in the realm of concepts. The 'ideas bound up in products' and the 'service wrap' allowed the USA and Europe to profit through trade in which they themselves were the biggest consumer, and, materially at least, not the producer.

I propose therefore that a knowledge economy is best understood not as a temporal concept of the latest stage of capitalism, but as a geographical one: it marks a spatial reorganization of production. Moreover, a knowledge economy seeks to recreate a geography of value, in which it has the ideas, and others do the work. It may seem as though capital is produced in the USA and Europe by the mere exchange of ideas, but 'ideas' often denote ownership of the production chain, which secures the repatriation of profits. It was this organization of the economy that made it possible to create figures titled 'U.S. Multinationals sell three times more through foreign operations than through exports' (Figure 1).

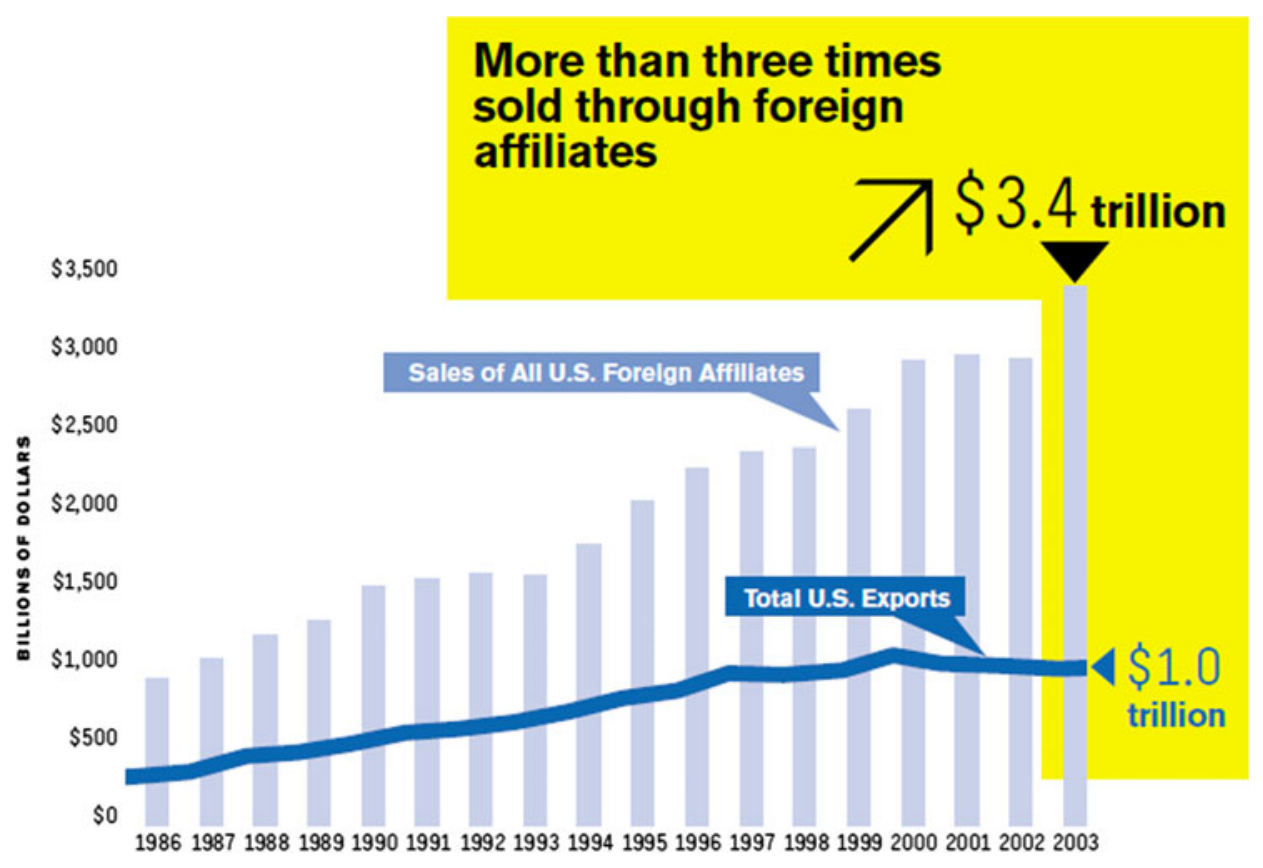

\section{FIGURE 1}

'US multinationals sell three times more through Foreign operations than through exports'. (c) Council on Competitiveness, 2006. 
That is, what this graph recounts is that thanks to the ownership of the production process - and despite the evacuation of production - the USA can still claim a seat at the center of economic production. That is why the location for ideation - 'designed in California' - is currently anything but immaterial.

\section{Modeling a Resourceful Future? Knowledge-adjusted GDPs}

Knowledge economies provide, indeed, a way to reevaluate deindustrialized settings as productive after all: they have the ideas, others do the work. This triumphant geography of value is also emerging in new mappings of economic processes, albeit with the help of significant adjustments. Economists, policy-makers, and politicians have their own tabular ways of organizing and mapping the economic world. The technoscientific practices of agencies like the Bureau of Economic Analysis (BEA), national censuses bureaus, the International Labor Organization, the Eurostat-Statistical Office of the European Communities, and the Organization for Economic Co-operation and Development capture imaginations of economies that are amongst others spatial in nature. Take the gross domestic product (GDP) - the measure for what services and goods are produced in a country. Its history is sometimes invoked to point out its effects on what is measured to be part of a national economy: what types of labor are included, for instance, or what types of goods and services are counted or left out. ${ }^{34}$ However, there is also a where to these models. The GDP is one of the most straightforward examples in its representations of national economies as spatially bounded and coherent entities (see Bergeron 2004, p. 4).

But recent metrics of economic activity have not necessarily located post-industrial nations as the center of economic production. That is, American and European national incomes have not grown as fast as others, the growth rate of output has been measly, labor productivity did not seem to increase much, and investments seemed low. One reason was the consumption-based economy, and the geographical organization of production that underpins it. Even if Americans were consuming 'American' goods - in the sense that they were designed, branded, and advertised in the USA - if the goods have been produced with low-cost industrial labor elsewhere they are counted as consumption of imported goods. Because most goods move into consumption-based economies - the goods are produced elsewhere, if one would look at the growth of the GDP (or the balance of trade) manufacturing economies like China and India would move front and center of the world economy. In other words, for quite a while the West (and other postindustrial sites) has been drifting off-center.

The geopolitical reorganization of production and the resulting bleak economic reports have been the impetus for recent searches for models that reframe this alarming picture. Policy-makers and economists have scrambled to alter rules for corporate accounting, national accounts, and industrial classification indices so they can recognize ideas as valuable products in and of themselves. I will discuss one example, the newly minted 'knowledge-adjusted GDP. ${ }^{35}$ In conventional accounts of the GDP, due to both the disintegrated production chains and the consumption binge in the West, the USA and Europe have come to be identified as net importers of goods, not net producers of goods. If the models no longer put Europe and the USA at the center of economic production, the thought seems to be that something must be wrong with the model. And if the economy in which they have found their bearings is tanking, they seek a new economy. Some economists and institutions have done just that, they have endeavored to produce a 
'knowledge-adjusted GDP.' This would include expenditures on research and development (R\&D), on entertainment, and on 'literary, and artistic originals' as fixed investment, as capital (BEA 2007, 2013a, 2013b; Corrado et al. 2006; Okubo et al. 2006; Eurostat 2014). ${ }^{36}$

These initiatives are typically buttressed by a narrative that common ways of measuring the economy do not depict the real traffic in valuable goods: 'The standard metrics of competitiveness that emphasize cross-border trade in goods no longer capture how and where value is created in the 21st century' (Council on Competitiveness 2006, p. 7). This is followed by a downplaying of the powers of current metrics: 'America's greatest competitive strengths - creating innovative new ideas, building global networks, managing global brands, marketing new products and services - are often the most difficult to measure' (Council on Competitiveness 2006 emphasis mine). Designing activities, for instance, were not counted by the bureau that tallies the GDP, the BEA. The Bureau did not count 'what Apple spends on R\&D and brand development.' Instead, 'they count[ed] each iPod twice: when it arrives from China, and when it sells. That, in effect, reduces Apple - one of the world's greatest innovators - to a reseller of imported goods' (Mandel et al. 2006, n.p.). The ensuing search for new models offers an interesting conundrum vis-à-vis our understanding of economic models. In the past decade, economic models have regularly been taken to task to not only represent but also to performatively call into being economic processes. ${ }^{37}$ Here, however, the economic models are accused by users to not represent 'what is really going on' - a discursive move that another set of critics, including anthropologists, feminists, and ecologists, would chime in with. $^{38}$

Alternative models that re-center knowledge economies have indeed been in the making. They would show, for example, that knowledge economies export products, even if they are only conceptual. Businessweek listed a number of changes in the economic narrative that would ensue if the GDP would be adjusted along these lines. These changes suggest how dangerously attractive these new models are. With a different metric:

- Investment has been rising as a share of the economy, rather than falling.

- The current account deficit was considerably smaller.

- The personal savings rate in 2005 was positive, not negative. ${ }^{39}$

- The part of the federal budget devoted to current spending was in balance.

- The 2001 recession was deeper than we thought. Current growth, however, may be stronger (Mandel et al. 2006, n.p.).

And indeed, this new model has taken effect in the USA on 31 July 2013 and is implemented in Europe in September 2014 (BEA 2013a, 2013b; Eurostat 2014). The shift prompted headlines in the USA such as 'Data shift to lift US economy 3\%' (Financial Times) and 'Yes, Lady Gaga's Songs Contribute to GDP' (Wall Street Journal). ${ }^{40}$ Here again, one can see that if the models no longer put Europe and the USA at the center of economic production, one comeback is to rethink what economic production is and to change the model accordingly.

As I discussed elsewhere, intangibles have sometimes been described as dark matter, as accounting 'for the fact that the world is more stable than you would think if it were held together only by the gravity emanating from visible matter' (Hausmann \& Stuzenegger 2005, p. 4, emphasis mine; 2006). ${ }^{41}$ In this article, I posit that it was actually economic instability that lies at the heart of this reconfiguration of what counts as economic production. ${ }^{42}$ Western economies have seen a steady decline in - and 
displacement of - economic production. My thesis is that the recent mobilization of a tangible/intangible divide (in for instance knowledge-adjusted GDPs) came into being as a way to contend with the fact that consumption goods are primarily produced elsewhere. The interest in intangibles reinforced a geography of value (and difference) in which knowledge economies had the ideas, and others did the work. Knowledge-adjusted models that incorporated intangibles helped to shore up the porous lines in this geography of value, by turning the repatriation of profits into a matter of fact. The focus on intangibles allowed for a revaluation of post-industrial economies as productive after all - they may not be producing any things, but they have the ideas. No wonder then that a text analyzed here to understand the paradoxical coexistence of progress and anxiety claims to provide an analysis that 'places the United States squarely in the center of an ever-changing, increasingly innovation-driven global economy' (Council of Competitiveness 2006, p. 98, emphasis mine). If ideas can be (re)labeled as the source of profits created in tangible production abroad, knowledge economies can reclaim their challenged sense as a center of a global productivity. The story of knowledge economies has thus comprised a combination of being wiped off the map of economic production and at the same time of endeavoring to redraw the map so that these post-industrial zones could regain their challenged sense of centrality in the world economy.

\section{Crisis and Conclusion}

In this article, I have argued that the focus on innovation/creativity and the narrative of ideational work has been intimately albeit awkwardly connected with a narrative of anxiety about growing economic competition. The framing of ideas and 'new kinds of value' as the 'engine' of economic growth was a sign of crisis: the 'base' of economic growth had eroded, at least geographically speaking. This gloomy picture of the demise and evacuation of manufacturing and service work has been a constitutive element in a narrative of progress - knowledge economies should focus on knowledge and ideas because they cannot compete in the realm of standardized labor. In this article, I have claimed that this focus on knowledge is, first, an anxious response to low-wage industrial labor elsewhere. Second, it is based on the availability of this low-wage industrial labor. And third, the focus on knowledge is a way to reclaim a seat at the center of economic production.

I have proposed that a knowledge economy marks only a relative shift in economic production - and more a spatial than a temporal one. While the term knowledge economy is usually reserved to shore up the capacity to produce profits in seemingly autonomous sites like the USA, The Netherlands, Taiwan, and Singapore, a spatial approach calls attention to the low-wage venues that are an inextricable if invisible element of these economies. A spatial approach showcases that the present is more usefully framed as a moment of multiple coexisting economies. Current knowledge economies are coeval with manufacturing economies: the valorization of ideas connotes not so much a superseding of industrial economies but a spatial displacement of production processes. Even though a knowledge economy prides itself as a next stage of civilizational existence - and economic production - without the plethora of offshored production processes, there would be no knowledge economy. Thus, while it embodies a shift in the regime of production, a knowledge economy is also a continuation of a manufacturing economy, albeit 'elsewhere.' 
Enfolding defeat with progress is a classic move in the framing of economic transformations. But a rhetorical similitude with earlier transformations does not rubber stamp a knowledge economy as a sustainable - and only - way forward. A spatial approach to the concept of a knowledge economy brackets the delirious yet provincial charisma of creativity and intuition, and includes, by definition, the transnational organization of production, in which ideas are often related more to control of the chain of production than with intellectual pursuits. This spatial approach redirects public discussion toward an assessment of current and future production arrangements, and to the question what productive activities and economic interconnections may be sustainable in times to come.

The orientalist line from the $B B C$ News that I quoted earlier in this article, that China is productive but lacks the brains, was at the end of the story toned down, with an admission that China too may become productive of ideas. The news story 'may be changing. China appears to be becoming more creative' (BBC News 2007, n.p.). Of course it is (see e.g. Pang 2012). The dream in which the demise of old economies can be wrapped in a celebratory narrative of a great leap forward, in which Western brains, intuition, ingenuity, and creativity will float so-called knowledge economies back to the center of the world economy, may turn out to be just that, a dream.

\section{ACKNOWLEDGMENTS}

Research for this article was funded by a University of California Chancellor's Fellowship, UvA Employability Fund Fellowship, Catharina van Tussenbroek Fellowship, and Henriette 575 Sara De Lanoy Meijer Fellowship. I thank Susan Harding, Carel Smith, Lisa Rofel, Jack Amariglio, Susan Bergeron, Donald Brenneis, Bruce Norton, Rachel Levin and Peter-Wim Zuidhof for their thoughtful comments. I would like to express my gratitude to the two anonymous reviewers for their astute insights.

\section{NOTES}

1. The Council on Competitiveness is an American lobby organization. Godin (2004) describes the context of its emergence, characterized by concerns over a 'competitiveness crisis' due to a negative trade balance. Since its inception in 1986, its members, hailing from industry, labor, and universities, have sought to 'eleva[te] national competitiveness to the forefront of national consciousness' in the USA. See http:// www.compete.org/about-us/history/.

2. See for instance Corrado et al. (2006), DeLong and Summer (2001), Florida (2004), Lévy and Jouyet (2006), Moulier Boutang (2011, p. 11).

3. For example, Van den Berg et al. (2005), Feser et al. (1998), Hudson (2009).

4. This paper focuses primarily on the juxtaposition of manufacturing and knowledge economies. Services are affected by the reorganization of production as well. Some services have been subsumed in the notion of a knowledge economy. In the industrial classification index, for instance, a number of services, such as business services, educational services, and publishing, were aggregated in 1997 in a newly organized category, 'information economy' (Knott Malone \& Elichirigoity 2003, p. 514). On the other hand, services have become subject to outsourcing processes. Standardized services in 
call centers or back-office work such as data processing and accounting have been outsourced. Labor in what is called the advanced service sector - financial services, consulting firms, and management instruction - is currently less outsourced, and more likely to be labeled 'knowledge work' (Taylor 2011; also Palm 2006).

5. Geographical shorthands like the 'West' and 'elsewhere' are highly problematic. Throughout this paper, I develop the point that the label of a knowledge economy functions as a positioning device. It offers countries facing a crisis in manufacturing competitiveness - mostly though not exclusively western countries - a way to imagine themselves as the center of economic production. In so doing, the notion of a knowledge economy also, precariously, reframes the relations between nations in industrial decline and the current centers of industrial production. The latter are, from the point of view of a knowledge economy, the 'elsewhere' I refer to. Both a knowledge economy and the 'elsewhere' it depends on are unstable and interdependent labels. For instance, faced with emerging competition in industrial labor, Taiwan set out to transition from a manufacturing economy to an economy based on culture and creativity in 2010, fashioning itself as an emerging knowledge economy (Wang et al. 2010). My point is that a knowledge economy is a geographical mapping device. Taiwan's understanding of itself as a knowledge economy also reframes its relation with overseas production areas (Taiwan's elsewhere), offering Taiwan once again a central role in economic production.

6. A notable and interesting exception to this pattern is Fritz Machlup, who was one of the first economists to perform a systematic analysis of the role of knowledge in economic processes. His classic book The Production and Distribution of Knowledge in the United States (1962) is an optimistic study of the role of technological progress in the US economy. This confident outlook does not reframe an otherwise gloomy picture (in his study, manufacturing continues to thrive in the USA alongside widespread knowledge production). Rather, it exudes an unfettered postwar expectation of an ever more modern world.

7. 'Conceptual economy' is the term that Allan Greenspan used to describe a knowledge economy. He argued that 'the fraction of the total output of our economy that is essentially conceptual rather than physical has been rising' (2003, n.p.). With the diagnosis of an 'increasing conceptualization of U.S. Gross Domestic Product' Greenspan argued that economic production was decreasingly a matter of raw materials, and increasingly a process revolving around the value of ideas, entangled or not in material products and processes. 'Over the past half century, the increase in the value of raw materials has accounted for only a fraction of the overall growth of U.S. gross domestic product,' he said, and 'the rest of that growth reflects the embodiment of ideas in products and services that consumers value' (2003, n.p.). Greenspan has repeated versions of this statement for more than a decade. The speeches can be found on http:// fraser.stlouisfed.org/publication/?pid $=452$.

8. The specifics of this periodization are subject to change. One of the first writers on a knowledge economy, Peter Drucker, saw a knowledge economy as primarily postagricultural. The transition from the nineteenth into the twentieth century, according to Drucker, could be characterized as a transition from agriculture to knowledge: 'Where the farmer was the backbone of any economy a century or two ago ... knowledge is now the main cost, the main investment, and the main product of the advanced economy and the livelihood of the largest group of the population' (Drucker 1968, p. 264). Walter Powell and Kaisa Snellman (2004, p. 215) invoke the temporal stages by describing a 
transition from an industrial economy 'based on natural resources and physical inputs' to an economy 'based on intellectual assets' (see also Florida 2004; Etzkowitz \& Webster 1995, p. 481). In his book Cognitive Capitalism, Yann Moulier Boutang also uses a temporal stage rhetoric, describing mercantile, industrial, and then cognitive capitalism (2011, p. 50). The latter was no longer based on machines and manual labor, but on 'immaterial investment,' that is, on knowledge and creativity (Yann Moulier Boutang 2011, p. 56-57).

9. In Europe the European Union's 'Lisbon Strategy' explicitly sought to remake Europe into a knowledge economy by 2010 (European Commission 2000). The year 2009 was, rather forlornly in the middle of an economic crisis, called the European Year of Creativity and Innovation. While the Lisbon Strategy was subsequently labeled a failure, the ensuing 'Europe 2020' calls for 'Smart growth,' the development of 'an economy based on knowledge and innovation' (European Commission 2010). For the USA, see footnote 7.

10. The European Policy Center is a think tank 'committed to make European integration work.' Its members hail from corporations and trade unions, as well as diplomatic missions, NGOs and religious organizations. See http://www.epc.eu/about.php (accessed May 13, 2013). Rosamond (2002) usefully shows how the notion of 'competitiveness' has contributed to the imagination of Europe as an economic entity.

11. Kong et al. (2006) provide an interesting analysis of the varied appropriations and adaptions of the concept in Asia. Hong Kong, Singapore, Taiwan, and South Korea stand out as most forcefully embracing the knowledge economy policy discourse. China showcases a mixed picture, it invests both in knowledge-intensive and in labor-intensive industries (Kong et al. 2006; see also Keane 2007, 2009a, 2009b). Taiwan is an example of a formerly low-wage industrial production center that, when it lost its competitive edge, sought to relabel itself as a knowledge economy. Its six-year Challenge 2008: National Development Plan (Taiwan R.O.C. Executive Yuan 2002) called for a reorganization of production:

With the cost of production rising and developing nations catching up fast, Taiwan's manufacturing sector has found itself in a difficult situation. Large-scale manufacturing operations no longer enjoy competitive advantage in Taiwan. In order to create new sources of competitive advantage, Taiwanese industry needs to adopt the new concepts of the knowledge economy, developing new areas of production where innovative design is the core element. Only then it will be possible for Taiwanese companies to differentiate themselves from their overseas competitors and create more value added (Wang et al. 2010)

12. Lehman in the documentary RIP: A Remix Manifesto (2009).

13. Even critics of the current web of intellectual property law and trade regulations seem to take the intellectual part of intellectual property somewhat for granted, arguing e.g. that 'ideas are more profitable than oil or land' (RIP Remix Manifesto 2009). That is, creative commons activists (with Lawrence Lessig as an excellent protagonist, 2001) share with advocates of tighter intellectual property rules that ideas and intangibles are valuable. In so doing, they seem to take the very separation of tangible and intangible property, as well as the organization of production that underpins this separation, for granted.

14. Lehman's interview ends with a somewhat dejected reflection that China has not returned the favor of US imports by complying with US copyright law. 'The idea was that 
in order for us to import manufactured goods, the government that exported to us would have to comply with US copyright law. We met our part of the bargain...' (2009).

15. The history of deindustrialization is of course a longer one. See Bluestone and Harrison (1982), Cowie and Heathcott (2003), High (2003), High and Lewis (2007).

16. For studies of supply chain capitalism, see Ong (1999, 2006), Ong and Collier (2005), Sassen (2006), Tsing (2009).

17. Harry Braverman (1974), in a searing critique of the effects of scientific management, prefers the terms 'execution' for manual labor, and 'conception' for intellectual labor.

18. He cast himself in the third person.

19. The study had first been presented as a keynote address to the American Society of Mechanical Engineers in 1906. Taylor's studies came about in a time when the study of 'work' was well under way in Europe (Rabinbach 1990, pp. 238-271).

20. The history of accounting is intimately entwined with the history of scientific management, see Van Eekelen (2010), and Miller (1998, pp. 185-188).

21. See also Sohn-Rethel (1978, p. 151) and Braverman (1974, p. 77).

22. Another explicit statement of the transfer of power can be found in a description of his objectives: 'taking the control of the machine shop out of the hands of the many workmen, and placing it completely in the hands of the management, thus superseding the "rule of thumb" by scientific control' (Taylor 1907, pp. 11-12, paragraph 52).

23. See fn. 16.

24. Call center work has been made geographically flexible through programs that teach workers to sound, for instance, 'generically' American (McMillin 2006, Mirchandani 2004). It is important to remember that this organization of production continues to be premised on a certain exchange rate. If the dollar were to fall deeply, the discourse may shift, and a new economy and inflection might have to be conjured.

25. For a history of how creativity is deemed to resist standardization, see Van Eekelen (2010).

26. A knowledge economy recodes not only the crisis in economic production, but also the vanishing of manufacturing and standard service work that provided enough to make a living. By squeezing 'work' out of this narrative, it seems as if economic production proliferates through entrepreneurial spirits. A knowledge economy does interpellate people, but through a discourse not of work but of a 'freedom' to undertake new things. In the process, any kind of collective solidarity, such as unionized labor or social security, is weeded out. The call on workers to become creative entrepreneurs who mold themselves without any safety net thus articulates the demise of the welfare state without any of the friction that this culling of forms of security might otherwise entail (see Van Eekelen 2010).

27. A knowledge economy is, in that sense, a code word for what Anna Tsing calls the organization of difference. Tsing (2009) shows how supply chains are a way to organize production through the mobilization of difference. It is beyond the scope of this study, but it would be productive to analyze how exactly knowledge economies and supply chains are imbricated, and in what particular ways they mobilize and organize difference.

28. This should be seen in conjunction with a booming financial sector. According to Brenner, the focus on consumption and imports was paired with a shift toward financial markets as an instrument for economic growth. 'Instead of supporting growth by increasing its own borrowing and deficit spending - as with traditional Keynesianism the government would ... stimulate expansion by enabling corporations and rich 
households to increase their borrowing and deficit spending by making them wealthier (at least on paper) by encouraging speculation in equities' (2009, p. 10). Brenner calls this 'asset-price Keynesianism' (see also Ho 2009).

29. For an analysis of new accounting practices that seek to codify intangible capital, see Van Eekelen (2010, manuscript under review).

30. 'High value' is a term used to describe activities and processes that purportedly wield much profit (see e.g. European Policy Centre 2009). My point is that the term 'high-value' reflects how value is recognized, attributed, and accounted for, rather than how (and where) it is produced.

31. Etzkowitz and Webster (1995), Imparato (1999), Lessig (2001), Lev (2001), Shapiro and Hassett (2005).

32. The Council on Competitiveness calls for an increase in protection of intellectual property, a topic that has, according to the Council, 'received too little attention in the public debate about competitiveness and innovation.' It continues: 'As global trade occurs increasingly in knowledge and intangibles, providing the global trading system with solid rules and regulations that defend intellectual property rights becomes more and more important' (Council on Competitiveness 2006, p. 59).

33. See also Eekelen (2010). This idea centrism has far-reaching effects. The Council on Competitiveness encouraged, for instance, a shift from formal rule-based education toward training in the development of creative and ingenious problem-solving skills (2006, p. 90). And indeed, in the USA, university courses in creative thinking are on the rise in response to perceived economic need (Berrett 2013).

34. For a history of its emergence, see Marcuss and Kane (2007), Mitchell (1998, 2002).

35. For a study of the changes in census, accounting and national accounts practices that seek to incorporate knowledge, see Eekelen (2010, manuscript under review).

36. See also www.bea.gov/gdp-revisions.

37. For example, MacKenzie et al. (2007), in particular Callon's chapter (2007).

38. The claim that economic models do not capture 'what is really going on' is a recurrent critique in disciplines such as feminist economics (e.g. Nelson 1995; Strober 2003) and economic anthropology (e.g. Gudeman 2008).

39. Here you see the effect of relabeling intangibles: it is no longer a form of immediate consumption, but future-oriented investment.

40. Harding (2013), Imasogie and Kobylarz (2013).

41. For discussions of the accounting category of 'intangible assets' see Lev (2001), Author (2010).

42. It could be argued that instability is inherent in capitalism, and that the destruction of its previous incarnations is the rule in capitalism rather than a state of exception (see Schumpeter 1928, 1943).

\section{REFERENCES}

BBC NEWS (2007) '"Sharp rise" in Chinese patents', 10 August, Available at: http://news.bbc.co.uk/ 2/hi/asia-pacific/6939767.stm

BERGERON, S. (2004) Fragments of Development: Nation, Gender, and the Space of Modernity, University of Michigan Press, Ann Arbor. 
BERRETT, D. (2013) 'Creativity: a cure for the common curriculum', The Chronicle of Higher Education, 1 April, Available at https://chronicle.com/article/The-Creativity-Cure/138203/ (accessed 10 November 2013).

BLUESTONE, B. \& HARRISON, B. (1982) The Deindustrialization of America: Plant Closings, Community Abandonment, and the Dismantling of Basic Industry, Basic Books, New York.

BRAVERMAN, H. (1974) Labor and Monopoly Capital: The Degradation of Work in the Twentieth Century, Monthly Review Press, New York.

BRENNER, R. (2009) What Is Good for Goldman Sachs Is Good for America: The Origins of the Present Crisis, Center for Social Theory and Comparative History UCLA, Los Angeles, pp. 1-74.

BUREAU OF ECONOMIC ANALYSIS (2007) 'FY 2008 budget request for the bureau of economic analysis', Available at: http://www.bea.gov/newsreleases/general/pdf/FY2008budgetfactsheet.pdf (accessed 12 March 2010)

BUREAU OF ECONOMIC ANALYSIS (2013a) 2013 Comprehensive Revision of the National Income and Product Accounts, Bureau of Economic Analysis, Washington. Available at: www.bea.gov/ gdp-revisions (accessed 8 November 2013).

BUREAU OF ECONOMIC ANALYSIS (2013b) Preview of the 2013 Comprehensive Revision of the National Income and Product Accounts. Changes in Definitions and Presentations, Bureau of Economic Analysis, Washington. Available at: www.bea.gov/gdp-revisions (accessed 8 November 2013).

CALLON, M. (2007) 'What does it mean to say that economics is performative?', in Do Economists Make Markets? On the Performativity of Economics, eds D. A. Mackenzie, F. Muniesa \& L. Siu, Princeton University Press, Princeton, pp. 311-357.

CORRADO, C., HULTEN, C. \& SICHEL, D. (2006) Intangible Capital and Economic Growth, Finance and Economics Discussion Series, Divisions of Research \& Statistics and Monetary Affairs, Federal Reserve Board, Washington, DC, pp. 1-48.

COUNCIL ON COMPETITIVENESS (2006) Competitiveness Index: Where America Stands, Council on Competitiveness, Washington, DC, pp. 1-116.

COWIE, J. R. \& HEATHCOT, J. (2003) Beyond the Ruins: The Meanings of Deindustrialization, ILR Press, Ithaca.

Delong, J. B. \& SUMmeRS, L. H. (2001) The 'New Economy': Background, Historical Perspective, Questions, and Speculations, Federal Reserve Bank of Kansas City, Kansas City, pp. 29-59. DRUCKER, P. F. (1968) The Age of Discontinuity: Guidelines to Our Changing Society, Harper \& Row, New York.

EEKELEN, B. VAN (2010) The Social Life of Ideas, Economies of Knowledge, PhD thesis, University of California, Santa Cruz.

EEKELEN, B. VAN (forthcoming) 'Accounting for ideas: bringing a knowledge economy into the picture', Manuscript under review.

ETZKOWITZ, H. \& WEBSTER, A. (1995) 'Science as intellectual property', in Handbook of Science and Technology Studies, eds S. Jasanoff, G. Markle, J. Peterson \& T. Pinch, Sage Publications, Thousand Oaks, CA, pp. 480-505.

EUROPEAN COMmission (2000) 'Presidency Conclusions', Lisbon European Council, 23-24 March, Available at: http://www.consilium.europa.eu/uedocs/cms_data/docs/pressdata/en/ec/00 100-r1.en0.htm (accessed 21 August 2012).

EUROPEAN COMMISSION (2010) 'Europe 2020', Available at: http://ec.europa.eu/commission_2010-2014/ president/news/documents/pdf/20100303_1_en.pdf (accessed 21 January 2014).

EUROPEAN POLICY CENTRE (2009) Europe's Knowledge Economy: Background Note, European Policy Centre, Brussels, n.p. 
EUROSTAT' (2014) 'European System of National and Regional Accounts 2010', Available at: http://epp. eurostat.ec.europa.eu/portal/page/portal/esa_2010/introduction (accessed 1 March 2014)

FERGUSON, J. (1999) Expectations of Modernity: Myths and Meanings of Urban Life on the Zambian Copperbelt, University of California Press, Berkeley, CA.

FESER, E. J., GOLDSTEIN, H. A., LUGER, M. I., \& NEMICKAS, A. (1998) At the Crossroads: North Carolina's Place in the Knowledge Economy of the Twenty-First Century, University of North Carolina, Department of City and Regional Planning, Chapel Hill.

FLORIDA, R. L. (2004) The Rise of the Creative Class: And How It's Transforming Work, Leisure, Community and Everyday Life, Basic Books, New York, NY.

GIBSON-GRAHAM, J. K. (1996) The End of Capitalism (as We Knew It): A Feminist Critique of Political Economy, Blackwell Publishers, Cambridge, MA.

GODIN, B. (2004) 'The obsession for competitiveness and its impact on statistics: the construction of high-technology indicators', Research Policy, vol. 33, no. 8, pp.1217-1229.

GREENSPAN, A. (2003) 'Market economies and rule of law', Financial Markets Conference, Federal Reserve Bank of Atlanta, Sea Island, Georgia, Available at: http://www.federalreserve.gov/ BoardDocs/speeches/2003/20030404/.

GUDEMAN, S. (2008) Economy's Tension: The Dialectics of Community and Market, Berghahn Books, New York.

HARDING, R. (2013) 'Data shift to lift US economy 3\%', Financial Times, 21 April, p. 1.

HAUSMANN, R. \& STURZENEGGER, F. (2005) US and Global Imbalances: Can Dark Matter Prevent a Big Bang?', Kennedy School of Government and Center for International Development, Cambridge, MA, n.p.

HAUSMANN, R. \& STURZENEGGER, F. (2006) 'Global imbalances or bad accounting? The missing dark matter in the wealth of nations', Center for International Development Working Paper No. 124, Center for International Development at Harvard University, Cambridge, pp. 1-42.

HIGH, S. C. (2003) Industrial Sunset: The Making of North America's Rust Belt, 1969-1984, University of Toronto Press, Toronto.

HIGH, S. C. \& LEWIS, D. W. (2007) Corporate Wasteland: The Landscape and Memory of Deindustrialization, IRL Press, Ithaca, NY.

HO, K. Z. (2009) Liquidated: An Ethnography of Wall Street, Duke University Press, Durham, NC.

HUDSON, R. (2009) 'From knowledge-based economy to... knowledge-based economy? Reflections on changes in the economy and development policies in the North East of England', Regional Studies, vol. 45, no. 7, pp. 997-1012.

IMASOGIE, O. \& KOBYLARZ, T. J. (2013) 'Yes, Lady Gaga's songs contribute to GDP. The new measure of the economy's output reflects the importance of intellectual property', Wall Street Journal, May 27. Available at: http://online.wsj.com/news/articles/SB100014241278873247 67004578491452865597808 (accessed 15 June 2013).

IMPARATO, N. (1999) Capital for Our Time: The Economic, Legal, and Management Challenges of Intellectual Capital, Hoover Institution Press, Stanford, CA.

KEANE, M. (2007) Created in China: The Great New Leap Forward, Routledge, London.

KEANE, M. (2009a) 'Creative industries in China: four perspectives on social transformation', International Journal of Cultural Policy, vol. 15, no. 4, pp. 431-443.

KEANE, M. (2009b) 'Great adaptations: China's creative clusters and the new social contract', Continuum: Journal of Media \& Cultural Studies, vol. 23, no. 2, pp. 221-230.

KNOTT MALONE, C. \& ELICHIRIGOITY, F. (2003) 'Information as commodity and economic sector', Journal of the American Society for Information Science and Technology, vol. 54, no. 6, pp. 512-520. 
KONG, L., GIBSON, C., KHOO, L. M., \& SEMPLE, A.-L. (2006) 'Knowledges of the creative economy: towards a relational geography of diffusion and adaptation in Asia', Asia Pacific Viewpoint, vol. 47, no. 2, pp. 173-194.

LEHMAN, B. (2009) 'RIP: A remix manifesto', Available at: http://topdocumentaryfilms.com/rip-remixmanifesto/ (accessed 21 August 2012).

LESSIG, L. (2001) The Future of Ideas: The Fate of the Commons in a Connected World, Random House, New York.

LEV, B. (2001) Intangibles: Management, Measurement, and Reporting, Brookings Institution Press, Washington, DC.

LÉVY, M. \& JOUYET, J. P. (2006) L'Économie de l'immatériel. La croissance de demain. Rapport de la commission sur l'économie de l'immatériel, Ministère de l'économie des finances et d'industrie, Paris, pp. 1-184.

MACHLUP, F. (1962) The Production and Distribution of Knowledge in the United States, Princeton University Press, Princeton, NJ.

MACKENZIE, D. A., MUNIESA, F. \& SIU, L. (2007) Do Economists Make Markets? On the Performativity of Economics, Princeton University Press, Princeton, NJ.

MANDEL, M., HAMM, S. \& FARREL, C. (2006) 'Why the economy is a lot stronger than you think', BusinessWeek, 13 February, 62-70.

MARCUSS, R. \& KANE, R. (2007) 'US national income and product statistics: born of the great depression and World War II', Survey of Current Business, vol. 87, no. 4, pp. 32-46.

MATSUURA, K., POLLITT, M., TAKADA, R., \& TANAKA, S. (2003) 'Institutional restructuring in the Japanese economy since 1985', Journal of Economic Issues, vol. 37, no. 4, pp. 999-1022.

MCMILLIN, D. C. (2006) 'Outsourcing identities: call centers and cultural transformation in India', Economic and Political Weekly, vol. 41, no. 3, pp. 235-241.

MILLER, P. (1998) 'The margins of accounting', in The Laws of the Markets, ed M. Callon, Blackwell Publishers, Oxford, pp. 174-193.

MIRCHANDANI, K. (2004) 'Practices of global capital: gaps, cracks and ironies in transnational call centers in India', Global networks, vol. 4, no. 4, pp. 355-373.

MITCHELL, T. (1998) 'Fixing the economy', Cultural Studies, vol. 12, no. 1, pp. 82-101.

MITCHELL, T. (2002) Rule of Experts: Egypt, Techno-Politics, Modernity, University of California Press, Berkeley, CA.

MOKYR, J. (2002) The Gifts of Athena: Historical Origins of the Knowledge Economy, Princeton University Press, Princeton, NJ.

MOULIeR BoUtAng, Y. (2011) Cognitive Capitalism, Polity Press, Cambridge, UK; Malden, MA.

NELSON, J. A. (1995) 'Feminism and economics', The Journal of Economic Perspectives, vol. 9, no. 2, pp. 131-148.

OKUBO, S., ROBBINS, C. A., MOYLAN, C. E., et al. (2006) 'BEA's 2006 Research and Development Satellite Account: Preliminary Estimates of R\&D for 1959-2002 Effect on GDP and Other Measures', Survey of Current Business, Bureau of Economic Analysis, Washington, DC, pp. 14-27.

ONG, A. (1999) Flexible Citizenship: The Cultural Logics of Transnationality, Duke University Press, Durham, NC.

ONG, A. (2006) Neoliberalism as Exception: Mutations in Citizenship and Sovereignty, Duke University Press, Durham, NC.

ONG, A. \& COLLIER, S. J. (2005) Global Assemblages: Technology, Politics, and Ethics as Anthropological Problems, Blackwell Publishing, Malden, MA.

OSAGIE, I. \& THADDEUS, J. K. (2013) 'Yes, Lady Gaga's Songs Contribute to Gdp', Wall Street Journal, p. A13. 
PALM, M. (2006) 'Outsourcing, self-service and the telemobility of work', Anthropology of Work Review, vol. 27, no. 2, pp. 1-9.

PANG, L. (2012) Creativity and Its Discontents: China's Creative Industries and Intellectual Property Rights Offenses, Duke University Press, Durham, NC.

POWELL, W. \& SNELLMAN, K. (2004) 'The knowledge economy', Annual Review of Sociology, vol. 30, pp. $199-220$.

RABINBACH, A. (1990) The Human Motor: Energy, Fatigue, and the Origins of Modernity, Basic Books, New York, NY.

RIP: A REMIX MANIFESTO (2009). Available at: http://topdocumentaryfilms.com/rip-remix-manifesto/ ROSAMOND, B. (2002) 'Imagining the European economy: "competitiveness" and the social construction of 'Europe' as an economic space', New Political Economy, vol. 7, no. 2, pp. 157-177.

SASSEN, S. (2006) Territory, Authority, Rights: From Medieval to Global Assemblages, Princeton University Press, Princeton, NJ.

SCHUMPETER, J. (1928) 'The instability of capitalism', The Economic Journal, vol. 38, no. 151, pp. 361-386.

SCHUMPETER, J. (1943) 'The process of creative destruction', in Capitalism, Socialism and Democracy, Allen and Unwin, London, pp. 81-86.

SHAPIRO, R. J. \& HASSET, K. A. (2005) 'The economic value of intellectual property'. Available at: http:// www.sonecon.com/docs/studies/IntellectualPropertyReport-October2005.pdf (accessed 20 August 2012).

SOHN-RETHEL, A. (1978) Intellectual and Manual Labour: A Critique of Epistemology, Humanities Press, Atlantic Highlands, NJ.

STROBER, M. H. (2003) 'The application of mainstream economics constructs to education: a feminist analysis', in Feminist Economics Today: Beyond Economic Man, eds M. A. Ferber \& J. A. Nelson, University of Chicago Press, Chicago, pp. 135-156.

TAIWAN R.O.C. EXECUTIVE YUAN (2002) Challenge 2008: National Development Plan, Taiwan Executive Yuan, Taipei.

TAYLOR, F. W. (1907) On the Art of Cutting Metals, The American Society of Mechanical Engineers, New York, NY.

TAYLOR, F. W. (1998 [1911]) The Principles of Scientific Management, Dover Publications, Mineola, NY.

TAYLOR, P. J. (2011) 'Advanced producer service centres in the world economy', in Global Urban Analysis: A Survey of Cities in Globalization, eds P. J., Taylor, P. Ni, B. Derudder et al. London, Earthscan, pp. 22-39.

TSING, A. (2009) 'Supply chains and the human condition', Rethinking Marxism, vol. 21, no. 2, pp. 149-176.

VAN DEN BERG, L., POL, P. M., VAN WINDEN, W., et al. (2005) European Cities in the Knowledge Economy: The Cases of Amsterdam, Dortmund, Eindhoven, Helsinki, Manchester, Munich, Münster, Rotterdam and Zaragoza, Ashgate Publishing Company, London.

WANG, B. C., LIU, S. C. \& CHOU, F. Y. (2010) 'National policy and promotion model of cultural and creative industry in Taiwan', International Journal of Business Research, vol. 10, no. 1, pp. 121-132.

Bregje van Eekelen Erasmus School of History, Culture and Communication, Department of History of Society Erasmus University Rotterdam, P.O. Box 1738, 3000 DR Rotterdam, The Netherlands. Email: vaneekelen@eshcc.eur.nl 